\title{
Occupied and unoccupied sage grouse habitat in Strawberry Valley, Utah
}

\author{
KEVIN D. BUNNELL, JERRAN T. FLINDERS, DEAN L. MITCHELL, AND JOHN H. WARDER
}

Authors are Research Associate Integrative Biology Department, Brigham Young University and Doctoral Candidate Forestry, Range and Wildlife Sciences Department, Utah State University, 5230 Old Main Hill, USU, Logan, Utah 84322; Professor, Integrative Biology Department, Brigham Young University, 401 WIDB, BYU, Provo, Utah 84602; Upland Game Coordinator, Utah Division of Wildlife Resources, P.O. Box 146301, Salt Lake City, Utah 84114; and Wildlife Biologist, Big Horn National Forest, 2013 Eastside $2^{\text {nd }}$ St., Sheridan, Wyo. 82801. At the time of the research the $4^{\text {th }}$ author was Wildlife Biologist, Uinta National Forest, P.O. Box 190, Heber, Utah 84302.

\section{Abstract}

This study evaluated multiple aspects of spring/summer sage grouse (Centrocercus urophasianus) habitat in Strawberry Valley, Utah by measuring vegetation associated with nest, brood and adult use sites. In addition, 3 types of random habitats were measured including available habitat within core use areas, random sagebrush (Artemisia spp.)/grass habitat outside core use areas, and random sagebrush/grass habitat sites that had been converted to an understory of smooth brome (Bromus inermis Leyss) by past range management practices. Logistic regression was used to identify those habitat variables that discriminated between site types. Variables that discriminated adult habitat from brood rearing habitat included: 1$)$ sagebrush height $(P \leq$ $0.01)$ and 2$)$ forb diversity $(P=0.12)$ with sagebrush height being greater at adult sites and forb diversity greater at brood sites Variables that significantly discriminated occupied adult habitat from random habitat outside of core use areas included: 1) percent grass cover $(\mathbf{P} \leq \mathbf{0 . 0 1})$ and 2$)$ area of sagebrush canopy $(\mathbf{P}=$ $\mathbf{0 . 0 3}$ ) with both variables having grater values in adult habitat. Variables that significantly discriminated occupied adult habitat from random habitat with a smooth brome understory included: 1) percent forb cover $(P \leq 0.01), 2)$ shrub canopy cover $(P=$ $0.02)$, and 3 ) area of sagebrush canopy $(P=0.08)$ with all variables being greater in adult habitat. In addition, this study identified sagebrush age, sagebrush canopy area, and forb diversity as potentially important aspects of sage grouse habitat that have not been previously reported.

Key Words: Centrocercus urophasianus, logistic regression, sagebrush, sage grouse

Sage grouse (Centrocercus urophasianus) habitat requirements have been studied in many different areas of their range and revised management guidelines have recently been published

\footnotetext{
Authors wish to thank Susan Durham and Stephen Bunnell for assistance in statistical analysis.

We thank Jon Rice and the Utah Reclamation Mitigation and Conservation Commission for their financial support of this research. We also thank Brigham Young University, the Utah Division of Wildlife Resources and the Uinta National Forest for additional funding and the use of equipment. We also thank Dave Stricklan, Lara Peterson, Leslie Tullis, Jackee Webber-Alston and Phalan Whitehair for their help in collecting data and Susan Durham and Stephen Bunnell for their statistical consultation.

Manuscript accepted 21 Jan. 04.
}

\section{Resumen}

Este estudio evaluó múltiples aspectos del hábitat primavera/verano del "Sage grouse" (Centrocercus urophasianus) en Strawberry Valley, Utah mediante la medición de la vegetación asociada con los nidos y el uso de sitios por los adultos y la camada. Además, se midieron 3 tipos de hábitats aleatorios, incluyendo el hábitat disponible dentro del área núcleo de uso, el hábitat aleatorio de "Sagebrush" (Artemisia spp.)/zacates fuera del área núcleo de uso y sitios del hábitat aleatorio de "Sagebrush"/zacates que habían sido convertidos a una cubierta vegetal herbácea de "Smooth brome" (Bromus inermis Leyss) por la prácticas de manejo del pastizal pasadas. Se uso regresión logística para identificar aquellas variables del hábitat que discriminaran entre tipos de sitios. Las variables que discriminaron el hábitat de adultos del hábitat para las crías incluyeron: 1) la altura del "Sagebrush" $(\mathbf{P} \leq \mathbf{0 . 0 1})$ y 2 ) la diversidad de hierbas $(P=0.12)$ siendo la altura del "Sagebrush"mas importante en los sitios para adultos y la diversidad de hierbas en los sitios para la camada. Las variables que discriminaron significativamente los hábitats ocupados por adultos de los hábitats aleatorios fuera del área núcleo de uso incluyeron: 1) porcentaje de cobertura de zacates $(P \leq 0.01)$ y 2$)$ área de la copa del "Sagebrush" ( $P=\mathbf{0 . 0 3})$ teniendo ambas variables valores mayores en los habitats para adultos. Las variables que discriminaron significativamente los hábitats ocupados de los hábitats aleatorios con una cobertura herbácea de "Smooth brome'incluyeron: 1) porcentaje de cobertura de hierbas ( $\mathrm{P} \leq$ 0.01), 2) cobertura de copa de arbustos $(P=0.02)$ y 3 ) área de copa del "Sagebrush" $(P=\mathbf{0 . 0 8})$ siendo todas la variables mayores en los habitats de adultos. Además, este estudio identifico la edad del "Sagebrush", el área de su copa y la diversidad de hierbas como aspectos potencialmente importantes del habitat del "Sage grouse"que no habían sido reportadas previamente.

(Connelly et al. 2000). From this collection of research, much has been learned about the vegetative habitat requirements for sage grouse at various life stages. Great attention has been given to sage grouse nesting habitat (Klebenow 1969, Peterson 1980, Wakkinen 1990, Gregg 1991, Connelly et al. 1991, Wakkinen et al. 1992, Fischer et al. 1993, Webb 1993, Gregg et al. 1994, Musil et al. 1994, Nelle 1998, Sveum et al. 1998 ), and brood rearing habitat (Gray 1967, Wallestad 1971, Klott and Lindzey 1990, Drut et al. 1994, Fischer et al. 1996, Nelle 1998, Sveum et al. 1998). Less attention has been given to adult spring/summer 
habitat requirements (Martin 1970, Wallestad and Schladweiller 1974, Braun et al. 1977, Schoenberg 1982, Hulet 1983, Martin 1990, Musil et al. 1994, Apa 1998). Few if any articles in professional journals have simultaneously evaluated vegetative spring/summer habitat requirements for an entire population. In addition, some important sagebrush characteristics have been neglected in relation to sage grouse habitat. For example, sagebrush stands have not been aged and only 1 study (Connelly et al. 1991) has measured the area within the canopy of sagebrush. Also, only 1 study (Dunn and Braun 1986) used multivariate statistical techniques to simultaneously analyze data. Although univariate statistics will detect differences that exist between site types (use sites and random sites for example) multivariate methods are needed to identify the variables that discriminate between site types and the relative importance of attributes at sites.

This study was needed to understand the 90 to $95 \%$ decline in the sage grouse population that has taken place over the past 60 years in the Strawberry Valley (based on a current population estimate of 150 sage grouse compared to a 1939 estimate of 3,000-4,000 (Griner 1939). Our objectives in this study were: 1) evaluate occupied sage grouse habitat in relationship to the recommended habitat guidelines, 2) identify those habitat variables that were selected for or against by sage grouse, and 3) evaluate habitat unoccupied by sage grouse and identify limiting factors that might be precluding use of these areas. We were particularly interested in evaluating the vegetative composition on sites where past range management practices resulted in native forbs and bunch grasses being replaced with an aggressive sodforming grass such as smooth brome (Bromus inermis Leyss), even though mountain big sagebrush (Artemisia tridentata vaseyna $\mathrm{Rydb}$.) had regrown on these sites. This particular research question may be relevant to many places other than Strawberry Valley, Utah. We believe this comprehensive approach was useful in identifying critical habitat characteristics as well as vegetation characteristics that may limit a sage grouse population.

\section{Materials and Methods}

This study was centered in the Strawberry Valley of north-central Utah (Latitude $40^{\circ} 08^{\prime} 38^{\prime \prime}$ Longitude $111^{\circ} 06^{\prime}$ 42") during 1998 and 1999. The area is a high mountain valley $(2,250-2,450 \mathrm{~m})$ and receives approximately $58 \mathrm{~cm}$ of annual precipitation. Strawberry Reservoir is the dominant feature of the valley covering up to 6,950 surface ha. Within the valley there are approximately 8,950 ha. of sagebrush/grass habitat which primarily border the reservoir. Mountain big sagebrush dominates the area with silver sage (Artemisia cana Pursh) occurring within wet meadows and riparian corridors. Historically sage grouse occupied most of the available sagebrush/grass habitat, but currently only occupy approximately 3,500 ha of the available habitat. Approximately 700 ha of the remaining unoccupied habitat has been converted to an understory of smooth brome. Livestock grazing was removed from the majority of the sagebrush/grass habitat surrounding the reservoir in 1989 (URMCC and USFS 1997) and none of the presently occupied habitat is grazed by livestock.

Sage grouse trapping was conducted during March, April, and May of 1998 and 1999 using the spotlighting method (Giesen et al. 1982). Necklace style radio telemetry transmitters (Marcstrom et al. 1989) were attached to captured sage grouse (males and females).

Seasonal habitat use was measured at sites occupied by radio collared birds. Once locations were identified they were classified as nest, brood, or adult habitat sites. In addition to radio telemetry, a trained German short-haired pointer was used to locate broods with uncollared hens. The following habitat measurements were taken at each site: slope, aspect, G.P.S. location, percent shrub canopy cover, percent herbaceous cover (by species), sagebrush and total shrub density, shrub decadence, horizontal obscurity cover, and vertical obscurity cover.

Percent sagebrush and total shrub canopy cover were measured using the line intercept method (Bonham 1989) along two, $50 \mathrm{~m}$ transects intersecting at the flush site. Sagebrush and total shrub densities were measured by two $\mathrm{T}^{2}$ analyses at each habitat point (Ludwig and Reynolds 1988). Each of the 4 shrubs in the two $\mathrm{T}^{2}$ analyses was measured for height and area within the canopy (calculated as the area of an ellipse). Percent decadence (defoliated or dying branches) was also estimated for each shrub. Percent occurrence of shrub species was calculated from the number of times each species occurred in the $\mathrm{T}^{2}$ analyses.

Herbaceous understory was quantified by estimating the percent cover of each species that occurred within a $1 / 4 \mathrm{~m}^{2}$ plot at the nest, brood or adult site (micro-habitat) and $25 \mathrm{~m}$ from the site in 4 directions (macro-habitat). Forb and grass diversity was calculated as the mean number of species occurring within understory plots.

Horizontal obscurity cover was measured using a $1 \mathrm{~m}^{2}$ cover board stratified into thirds $(0-33.3 \mathrm{~cm}, 33.3 \mathrm{~cm}-66.6 \mathrm{~cm}$ and $66.6 \mathrm{~cm}-100 \mathrm{~cm}$ ) along the vertical axis with each stratification separated into 12 equal squares. Horizontal obscurity cover measurements were taken at 25-35 $\mathrm{cm}$ above the ground at distances of $2.5,5$, and 10 meters from the cover board in 4 directions. Vertical obscurity cover was measured using an $18 \mathrm{~cm} \times 18 \mathrm{~cm}$ cover board, separated into 36 equal squares. This board was placed directly over the use site and the number of obscured squares was recorded when viewed from directly above.

In addition to identified use sites the following 3 types of random sagebrush habitats were also measured in the same manner: 1) random sites within occupied habitat (occupied habitat), 2) random habitat outside of the currently occupied habitat (available habitat), and 3) random habitat within the available habitat that had been converted to an understory of smooth brome by past range management practices (brome habitat). Brome habitat was separated from available habitat sites because the understory composition in these areas was obviously different. Available habitat was separated from occupied habitat because of a lack of use by radio collared or other sage grouse.

Occupied habitat sites were located by taking a random compass bearing from a use site and going $100 \mathrm{~m}$ in that direction. To assure independence of random sites a second random bearing and a random distance (up to $100 \mathrm{~m}$ ) were then used to arrive at the random habitat location. Occupied habitat sites were not further categorized as specific types of habitat because the randomization method assured their independence from a specific use site. Brome habitat sites and available habitat sites were also located by taking random compass bearings and random distances (as described above) from random point along a road in available and brome habitats.

During 1999 sagebrush ages were estimated at adult, random occupied, brome, and available habitat sites by cutting the sagebrush plant nearest to the data point (sagebrush was also aged for nest and brood sites, but sample sizes were small). Sagebrush cuttings were then sanded and the growth rings counted from the center 
Table 1. Classification table of logistic regression models.

\begin{tabular}{|c|c|c|c|c|c|c|c|c|}
\hline \multirow[t]{2}{*}{ Sites Compared* } & \multirow[t]{2}{*}{ Discriminating Variables } & \multicolumn{2}{|c|}{ Correct } & \multicolumn{2}{|c|}{ Incorrect } & \multirow[t]{2}{*}{ Correct } & \multirow[t]{2}{*}{ Sensitivity } & \multirow[t]{2}{*}{ Specificity } \\
\hline & & Event & Non-event & Event & Non-event & & & \\
\hline Adult vs. Random & $\begin{array}{l}\text { Sagebrush height, and } \\
\text { Sagebrush \% decadence }\end{array}$ & 35 & 44 & 20 & 23 & $\begin{array}{l}(\%) \\
64.8\end{array}$ & $\begin{array}{l}\%) \\
60.3\end{array}$ & $\begin{array}{l}(\%) \\
68.8\end{array}$ \\
\hline Adult vs. Brome & $\begin{array}{l}\% \text { Forb cover, Shrub canopy cover, } \\
\text { and Area of sagebrush canopy }\end{array}$ & 16 & 53 & 11 & 14 & 73.4 & 53.3 & 82.8 \\
\hline Adult vs Available & $\begin{array}{l}\% \text { Grass cover, and Sagebrush } \\
\text { canopy cover }\end{array}$ & 8 & 59 & 5 & 22 & 71.3 & 26.7 & 92.2 \\
\hline Adult vs Brood & Sagebrush height, and Forb diversity & 17 & 32 & 8 & 13 & 70.0 & 56.7 & 80.0 \\
\hline Brood vs Random & Forb diversity, and $\%$ Forb cover & 56 & 10 & 20 & 3 & 74.2 & 94.9 & 33.3 \\
\hline
\end{tabular}

*The first site type listed is the "event" and the second is the "non-event".

to the cork cambium with the aid of a microscope (Ferguson 1964). A minimum of 2 counts were made of each cutting by separate individuals. This process was repeated until agreement of the counts was reached.

Statistical analyses was done using Minitab ${ }^{\circledR}$ statistical software (release 13) and SAS ${ }^{\circledR}$ version 8. Comparisons of variables between site types were performed with a one-way ANOVA on each variable. Tukey's family significance levels (Tukey's P) were used within each ANOVA to make pairwise comparison between site types in order to avoid type I error rate inflation. Non-parametric statistical procedures were used to analyze differences between individual species in the understory between site types because these data did not meet the assumptions for ANOVA (data were not normally distributed and standard deviations were not equal).

A Kruskal-Wallis analysis was used in place of the ANOVA test and a MannWhitney test was used to make pairwise comparisons. Occurrence of shrub species was statistically analyzed for differences between site types with a chi-square test of homogeneity of proportions. Univariate statistical methods were first used to identify differences that existed between the 3 types of use sites and between use sites and random sites.

Logistic regression (Hosmer and Lemeshow 2000) was used to identify those variables that best discriminated between use and random habitat site types through stepwise elimination of the least significant variable. Percent concordance is reported with logistic regression analyses as a measure of the models ability to discriminate between the 2 dependent variables being tested. Percent concordance is the percentage of pairwise comparisons in which the event (use site) had a higher predicted probability according to the model. In addition Table 1 contains the classification criteria for all logistic regression models. All variables used in logistic regression models were checked for pairwise correlation to avoid problems associated with multicollinearity.

\section{Results}

Mean sagebrush age at adult sites and random occupied sites was significantly greater than at available habitat sites (Tukey's $\mathrm{P}=0.04$ and $\leq 0.01$ ) respectively. Sagebrush age for brome habitat sites was not significantly different from any other sites (Table 2).

Mean sagebrush canopy area was significantly greater at nest and adult sites than at all other sites (Tukey's $\mathrm{P} \leq 0.01$ ). Also, the canopy area of all shrubs species was significantly higher for adult and nest sites when compared to all other sites (Tukey's $\mathrm{P} \leq 0.01$ ) (Table 2).
Sagebrush plants were significantly taller at adult, nest and brome habitat sites than at all other sites (Tukey's $P \leq 0.01$ ). Also, all non-sagebrush shrubs were sig. nificantly taller at adult, nest and brome habitat sites than at all other sites (Tukey's $\mathrm{P} \leq 0.01$ ) (Table 2).

Mean percent decadence of sagebrush was significantly higher at adult, brome, and available habitat sites than at brood and occupied random habitat sites (Tukey's $\mathrm{P} \leq 0.01$ ). Also, percent decadence for non-sagebrush shrub species was significantly higher at adult sites than at random occupied habitat sites (Tukey's $\mathrm{P} \leq 0.01$ ) (Table 2).

Composition of shrub species appearing in the $\mathrm{T}^{2}$ analysis at adult sites was significantly different than at nest sites $(\mathrm{P}=$ 0.01 ), brood sites ( $P=0.021)$, and available habitat sites $(P=0.03)$. Composition of shrubs at nest sites was significantly different from brood sites ( $\mathrm{P} \leq 0.01$ ), random occupied habitat sites $(\mathrm{P}<0.001)$. brome sites $(P=0.005)$, and available habitat sites $(P \leq 0.01)$. Shrub species occurrence at brood sites was significantly different from random occupied habitat sites $(P \leq 0.01)$. In addition, the shrub composition at random occupied habitat sites was significantly different than at brome habitat sites $(\mathrm{P} \leq 0.01)$ (Fig. 1 . No significant differences were found in sagebrush or total shrub densities.

Table 2. Mean Mountain Big Sagebrush and other shrub characteristics measured in association with sage grouse habitats in Strawberry Valley.

\begin{tabular}{|c|c|c|c|c|c|c|c|}
\hline Habitat Type & $\begin{array}{l}\text { Sagebrush } \\
\text { Age }\end{array}$ & $\begin{array}{c}\text { Sagebrush } \\
\text { Canopy Area }\end{array}$ & $\begin{array}{c}\text { Shrub Canopy } \\
\text { Area }\end{array}$ & $\begin{array}{c}\text { Sagebrush } \\
\text { Height }\end{array}$ & $\begin{array}{l}\text { All Shrub } \\
\text { Height }\end{array}$ & $\begin{array}{l}\text { Sagebrush } \\
\text { Decadence }\end{array}$ & $\begin{array}{l}\text { All Shrub } \\
\text { Decadence }\end{array}$ \\
\hline & (yrs.) & $\left(\mathrm{m}^{2}\right)$ & $\left(\mathrm{m}^{2}\right)$ & $(\mathrm{cm})$ & $(\mathrm{cm})$ & $(\%)$ & $(\%)$ \\
\hline Adult $(n=64)$ & $20.5 \mathrm{a}$ & $1.3 \mathrm{a}$ & $1.2 \mathrm{a}$ & $54.1 \mathrm{a}$ & $51.1 \mathrm{a}$ & $30.0 \mathrm{a}$ & $25.0 \mathrm{a}$ \\
\hline Nest $(n=10)$ & - & $1.5 \mathrm{a}$ & $1.4 \mathrm{a}$ & $54.3 \mathrm{a}$ & $50.7 \mathrm{a}$ & $21.5 \mathrm{a} \mathrm{b}$ & $20.9 \mathrm{ab}$ \\
\hline Brood $(n=30)$ & - & $0.8 b$ & $0.8 b$ & $37.6 b$ & $37.1 \mathrm{~b}$ & $16.1 \mathrm{~b}$ & $19.0 \mathrm{a} \mathrm{b}$ \\
\hline Random Occupied $(n=55)$ & $22.8 \mathrm{a}$ & $0.9 \mathrm{~b}$ & $0.7 b$ & $42.7 b$ & $37.9 \mathrm{~b}$ & $16.8 \mathrm{~b}$ & $16.6 \mathrm{~b}$ \\
\hline Brome $(\mathrm{n}=30)$ & $20.2 \mathrm{a} \mathrm{b}$ & $0.8 b$ & $0.7 \mathrm{~b}$ & $49.9 \mathrm{a}$ & $48.7 \mathrm{a}$ & $26.8 \mathrm{a}$ & $23.3 \mathrm{ab}$ \\
\hline Available $(\mathrm{n}=30)$ & $16.6 b$ & $0.9 \mathrm{~b}$ & $0.7 b$ & $40.3 \mathrm{~b}$ & $39.0 \mathrm{~b}$ & $26.2 \mathrm{a}$ & $23.1 \mathrm{a} \mathrm{b}$ \\
\hline
\end{tabular}

Within each column, means with different letters are significantly different using Tukey's pairwise comparison ( $\mathrm{P} \leq 0.05)$ 


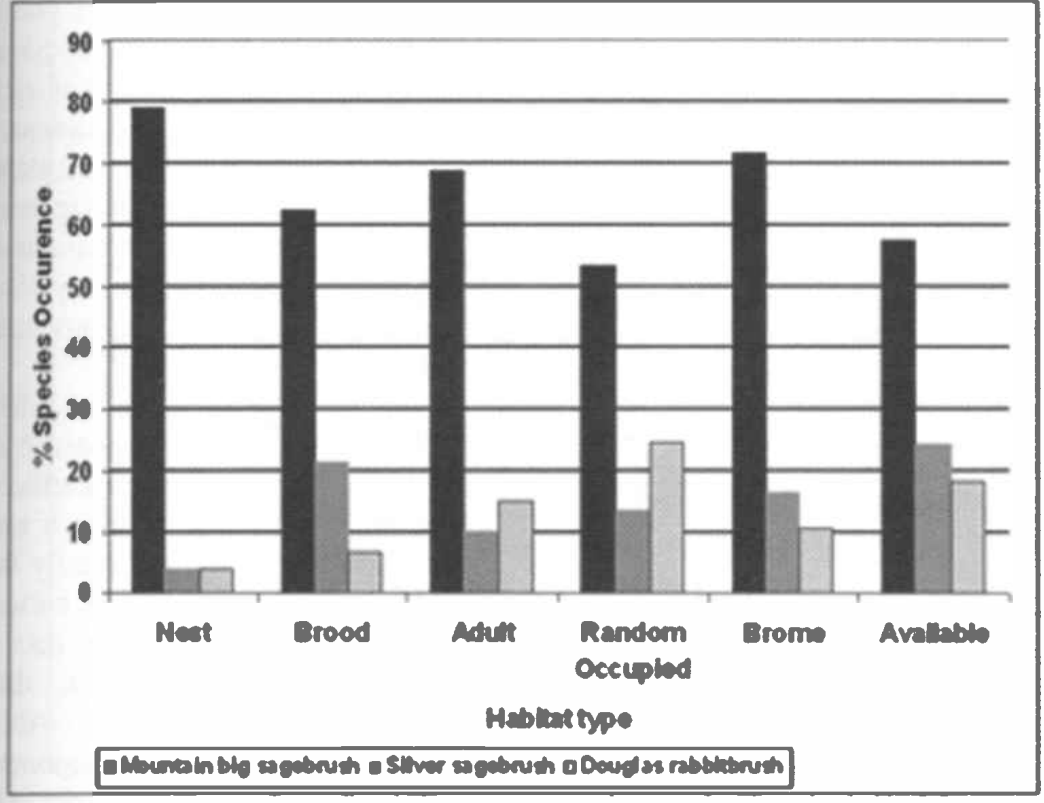

Fig. 1. Percent occurence of shrub species measured in association with sage grouse habitats in Strawberry Valley.

Sagebrush canopy area of the closest shrub $\left(\bar{x}=1.5 \mathrm{~m}^{2}\right)$ at adult sites was significantly greater than the second shrub $(\overline{\mathrm{x}}$ $\left.=1.3 \mathrm{~m}^{2}\right)$ in the $\mathrm{T}^{2}$ analyses $(\mathrm{P}=0.03)$. No other differences were found in the 4 shrubs measured at each adult site. No differences were found among the 4 shrubs measured at other use sites.

No statistical differences were found for sagebrush canopy cover between any site types. Total shrub canopy cover at brome sites was significantly less (Tukey's $\leq 0$ 01) from the total shrub canopy at all ther sites except nest sites which had a high standard deviation (19.2\%) possibly resulting from a small sample size $(\mathrm{n}=$ 10) (Table 3).

tat sites $(\mathrm{P} \leq 0.01)$. Smooth brome was not found in the understory at nest sites or random occupied sites (Table 4).

Total percent cover of the 14 most common forb species in understory plots was significantly lower at brome sites than at all other sites except nest sites (Tukey's P $\leq 0.01)$ and was significantly lower in available habitat than at brood sites and in occupied random habitat (Tukey's $\mathrm{P} \leq$ 0.01 ) (Table 5). Total forb cover was not significantly different between any other sites. Many significant differences were found between site types in the percent cover of the 14 most common forb species (Table 5). Forb species diversity (species/ $1 / 4 \mathrm{~m}^{2}$ ) was significantly lower in brome

Table 3. Mean percent canopy cover of mountain big sagebrush and all shrubs measured in association with sage grouse habitats in Strawberry Valley.

\begin{tabular}{lcccccc}
\hline \hline Site Type & Nest & Brood & Adult & $\begin{array}{c}\text { Random } \\
\text { Occupied } \\
(\mathrm{n}=55)\end{array}$ & $\begin{array}{c}\text { Brome } \\
\text { Habitat } \\
(\mathrm{n}=30)\end{array}$ & $\begin{array}{c}\text { Available } \\
\text { Habitat } \\
(\mathrm{n}=30)\end{array}$ \\
\hline & $-\mathrm{n}=10)$ & $(\mathrm{n}=30)$ & $(\mathrm{n}=64)$ & $-1 \%)$ \\
Sagebrush Canopy Cover & 24.8 & 22.9 & 24.7 & 23.2 & 18.5 & 20.2 \\
Total Shrub Canopy Cover & 36.3 & 33.4 & 33.9 & 35.1 & $23.3 *$ & 28.5 \\
\hline
\end{tabular}

'Statistically different from all other site types except nests sites (alpha $=0.05$ )

Total percent cover for grass in understory plots was significantly higher at brome sites than at all other site types (Tukey's $\mathrm{P} \leq 0.01$ ). Brome sites were the only areas with Timothy grass (Phleum spp.) in the understory. Percent cover of smooth brome was significantly higher at brome sites than at brood sites $(\mathrm{P} \leq 0.01)$, adult sites ( $\mathrm{P} \leq 0.01)$, and available habi- habitat $(0=1.9)$ than at brood sites $(\overline{\mathrm{x}}=$ 3.0) $(\mathrm{P} \leq 0.01)$, and adult sites $(0=2.7)$ $(\mathrm{P} \leq 0.01)$. Forb species diversity was also significantly lower in available habitat ( $\bar{x}$ $=2.0)$ than at brood $(\mathrm{P} \leq 0.01)$ and adult sites $(P \leq 0.01)$. Forb diversity at nest sites $(\overline{\mathrm{x}}=2.2)$ and random occupied habitat sites $(\bar{x}=2.4)$ was significantly lower than at brood sites $(\mathrm{P} \leq 0.01$, and $\mathrm{P} \leq$
$0.01)$ respectively, but did not differ significantly from adult sites (Fig. 2).

Mean horizontal obscurity cover tended to be highest at brome habitat sites and lowest at brood sites. These tendencies became more obvious at $67-100 \mathrm{~cm}$ above ground level, regardless of distance (Table 6).

Mean vertical cover was significantly higher at nest sites $(\bar{x}=97.7 \%)$ than at brood sites $(\overline{\mathrm{x}}=62.2 \%)(\mathrm{P} \leq 0.01)$ and adult sites $(\overline{\mathrm{x}}=63.4 \%)(\mathrm{P} \leq 0.01)$. There were no differences in slope between any site types, although within adult sites, males tended to select steeper slopes $(\overline{\mathrm{x}}=$ $11.31 \%)$ than females $(\bar{x}=4.37 \%)$.

Percent cover of forbs was significantly higher $(P=0.02)$ at brood micro-habitat sites than at brood macro-habitat sites (Fig 3 ). Forb species diversity was also higher $(P=0.07)$ in brood micro-habitat than brood macro-habitat (Fig. 4). No difference was found in percent cover of forbs or forb diversity in micro and macro habitats at adult sites (Figs. 3 and 4). There was no significant differences in percent cover of grasses in micro-habitats or macro-habitats for either brood sites (micro $\bar{x}=22.3 \%$, macro $\bar{x}=19.58 \%$ ) or adult sites (micro $\overline{\mathrm{x}}=26.4 \%$, macro $\overline{\mathrm{x}}=$ $24.1 \%$ ). Micro and macro habitats were not analyzed for nest sites because of an insufficient sample size $(n=10)$. Total percent forb cover was the only variable with significant predicative value $(\mathrm{P}=$ 0.02 ) in distinguishing micro habitat from macro habitat at brood sites in a logistic regression that started with the 14 most common forb species and total forb cover as independent variables (concordance = $61.9 \%$ ).

Logistic regression was used to identify those variables that significantly contributed to distinguishing adult sites from all random site types. Adult use sites were important to the analyses because they were the most general habitat sites used by sage grouse. The only variables significant in distinguishing adult sites from occupied habitat sites were sagebrush height $(\mathrm{P} \leq$ $0.01)$ and sagebrush decadence $(\mathrm{P}=$ $0.016)$ (concordance $=75.4 \%$ ) with both sagebrush height and decadence greater at adult sites than at random sites in occupied habitat (Tables 1 and 2). Percent grass cover $(P \leq 0.01)$ and sagebrush canopy area $(P=0.03)$ were variables significant in distinguishing adult sites from available habitat sites (concordance $=70.3 \%$ ) with both grass cover and sagebrush canopy area greater at adult sites (Tables 2, 4, and 1). Percent forb cover $(\mathrm{P} \leq 0.01)$, shrub canopy cover $(P=0.02)$, and area of sagebrush canopy $(P=0.08)$, were those vari- 


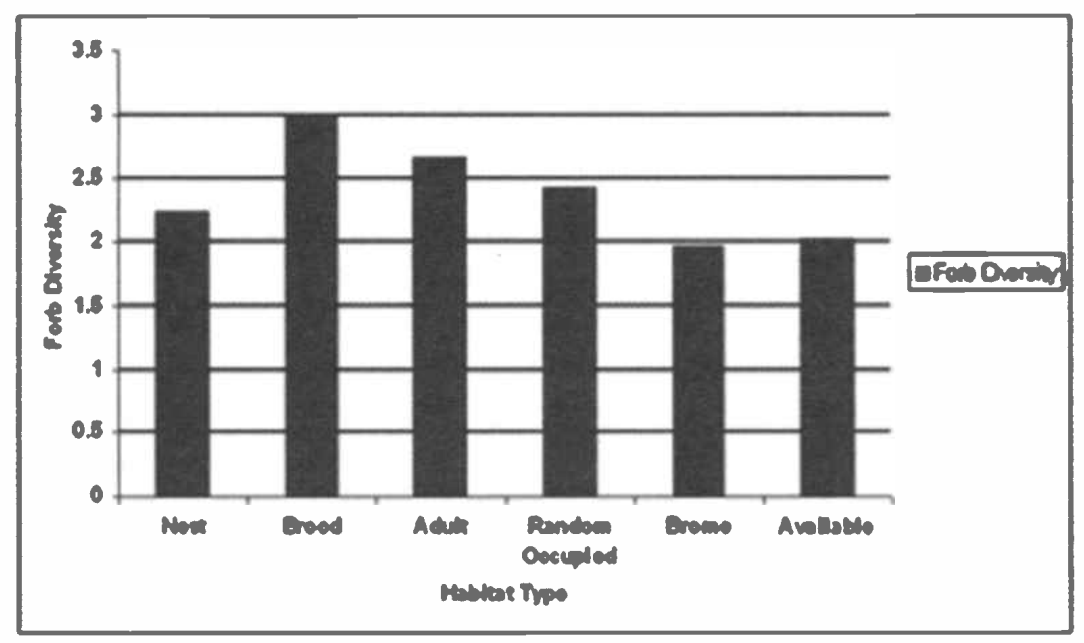

Fig. 2. Forb diversity (species $/ 1 / 4 \mathrm{~m}^{2}$ ) measured in association with sage grouse habitats in Strawberry Valley.

ables proving significant in distinguishing adult sites from brome habitat sites (concordance $=79.9 \%$ ) with all distinguishing variables having greater mean values in adult habitat (Tables 2, 5, and 1).

Logistic regression was also used to identify the variables that discriminate brood habitat from adult habitat and occupied habitat sites. Sagebrush height $(\mathrm{P}=$ $0.05)$ and forb diversity ( $\mathrm{P} \leq 0.01)$ were the most significant variables in discriminating brood and adult habitats (concordance $=74.9 \%)($ Tables 2 and 5$)$. Forb diversity $(P \leq 0.01)$ and forb cover $(P \leq$ 0.01 ) were the only variables that contributed to discriminating brood sites from random occupied habitat sites (concordance $=68.4 \%)($ Tables 5 and 1) (Fig. 2). Nest sites were not included in logistic regression comparisons because of insufficient sample sizes.

\section{Discussion}

One of the unique contributions of this study to the knowledge of sage grouse habitat is that several habitats were identified and measured simultaneously for a single population. Only 1 other study (Dunn and Braun 1986) reported similar data, but with fewer kinds of habitats.

Measurements of sagebrush and other shrub canopy areas showed sage grouse selected shrubs having greater canopy area for nest and adult habitat than was found at all other habitats. Our measurements of sagebrush canopy size at nest sites were similar to those of Connelly et al. 1991 $\left(1.53 \mathrm{~m}^{2}\right.$ compared to $\left.1.19 \mathrm{~m}^{2}\right)$. It is not surprising that canopy area at brood sites was lower than at nest, and adult sites. It has been well documented that sage grouse seek areas with lower sagebrush canopy cover and greater access to succulent forbs for brood habitat (Klebenow 1969, Klott and Lindzey 1990, Drut et al 1994).

Sagebrush and other shrub heights were significantly greater at adult, nest and brome sites than at other sites. These findings support other research that found sage grouse nest beneath taller sagebrush plants than are randomly available (Klebenow 1969 and Sveum et al. 1998). However, neither height nor canopy area differed between nest sites and adult sites which suggests hens may not be choosing bigger/taller shrubs specifically for nesting activities, but merely selecting shrubs they typically find suitable. A larger sample of nest sites is needed to investigate this theory.

Sagebrush was significantly more decadent at adult sites than at nest sites, even though the ages of the shrubs did not differ. This difference may possibly be explained by the time of year that estimates of decadence were made. Sagebrush decadence, at nest sites, was estimated

Table 4. Mean percent cover of grass species measured at sage grouse habitat sites in Strawberry Valley.

\begin{tabular}{|c|c|c|c|c|c|c|}
\hline $\begin{array}{l}\text { Site } \\
\text { Type }\end{array}$ & $\begin{array}{c}\text { Nest } \\
(\mathrm{n}=10)\end{array}$ & $\begin{array}{c}\text { Brood } \\
(n=30)\end{array}$ & $\begin{array}{c}\text { Adult } \\
(\mathrm{n}=64)\end{array}$ & $\begin{array}{l}\text { Random } \\
\text { Occupied } \\
(\mathrm{n}=55)\end{array}$ & $\begin{array}{l}\text { Brome } \\
(\mathrm{n}=30)\end{array}$ & $\begin{array}{c}\text { Available } \\
(\mathrm{n}=30)\end{array}$ \\
\hline Smooth Brome & 0.0 & $0.1 \mathrm{e}$ & $0.2 \mathrm{e}^{\mathrm{c}}$ & $0.2 \mathrm{e}$ & $21.8 \mathrm{bcd}$ & 0.0 \\
\hline Phleum spp. & 0.0 & 0.0 & 0.0 & 0.0 & 1.7 & 0.0 \\
\hline Carex spp. & $\begin{array}{l}0.9 \text { ef } \\
0.01 \text { abd }\end{array}$ & $2.1 \mathrm{cdef}$ & $0.3 \mathrm{~b}$ & 0.7 ef & $0.2 \mathrm{abd}$ & \\
\hline Stipa spp. & $0.3 \mathrm{bcdf}$ & $1.3 \mathrm{f}$ & $1.1 \mathrm{f}$ & $1.6 \mathrm{f}$ & 0.0 & $3.7 \mathrm{abcd}$ \\
\hline Poa spp. & $\begin{array}{l}16.7 \mathrm{e} \\
7.7 \mathrm{abcdf}\end{array}$ & $\begin{array}{l}14.6 \mathrm{ce} \\
15.9 \mathrm{e}\end{array}$ & 19.2 be & $17.9 \mathrm{e}$ & & \\
\hline Agropyron spp. & $3.2 \mathrm{e}$ & $1.7 \mathrm{e}$ & $3.7 \mathrm{def}$ & $2.4 \mathrm{ef}$ & $0.3 \mathrm{abcdf}$ & 1.8 \\
\hline Total Grass & $21.1 \mathrm{e}$ & $19.9 \mathrm{e}$ & $24.6 \mathrm{e}$ & $22.8 \mathrm{e}$ & 31.9 abcdf & $21.5 \mathrm{e}$ \\
\hline
\end{tabular}
decadence at adult sites was estimated throughout the spring and summer which stressed. The finding that sagebrush was also more decadent at available habitat sites than at other sites may show that these sites are simply less productive due to edaphic factors (Table 2).

adult habitat neither sagebrush canopy criminating variables. Rather, it was sagebrush height and forb diversity that best discriminated between these critical habitats (Table 2) (Fig. 1). These data conflict brush canopy cover and forb cover are the most important habitat components that separate these two habitat types. Although these data may be a reflection of our study ty to forb cover and sagebrush height to sagebrush canopy cover in sage grouse brood habitat merits further investigation. As in other studies, (Peterson 1980 Autenrieth 1981, Dunn and Braun 1986, Apa 1998, Sveum et al. 1998) sage grouse broods in our study site were found in areas with high forb cover and diversity. We made a more detailed study of forbs by documenting a higher and more diverse
forb component not only when broed sites were compared to other use and random sites, but also when brood micro-habitat was compared to brood macro-habitat. These data are important since the forb component in the macro-habitat was well
within the recommended guideline (Connelly et al. 2000) for percent cover of forbs in brood habitat and yet, sage grouse broods still selected micro-habitats with significantly greater forb cover (Fig. 2)
and diversity (Fig. 3). Recall, logistic and diversity (Fig. 3). Recall, logisti

Within each column letters indicate site types that are significantly different $(\mathrm{P}<0.05)$ from the column site type $(\mathrm{a}=$ nest, $\mathrm{b}=$ brood, $\mathrm{c}=$ adult, $\mathrm{d}=$ random occupied, $\mathrm{e}=$ brome, $\mathrm{f}=$ available) for the row species. 


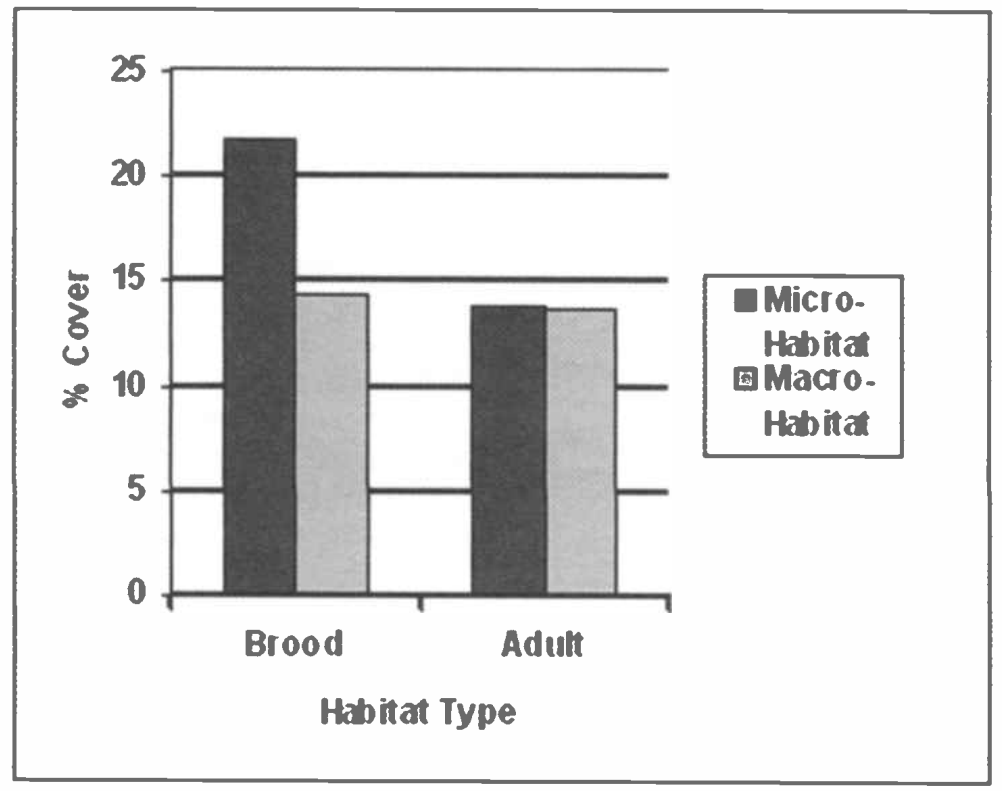

Fig. 3. Percent forb cover in micro and macro sage grouse habitat measured at brood and adult habitat sites in Strawberry Valley.

regression did not identify any particular forb species as being a significant predictor of brood micro-habitat when compared to brood macro-habitat and yet total forb cover was significantly different. This suggests that hens with broods did not key on any particular forb species when a diverse suite of species was available. Rather, they selected habitat based on the overall abundance of forbs. We did not find any differences in forb cover (Fig. 2) ar diversity (Fig. 3) between adult micro and macro habitat suggesting that forb cover may not be as important as other habitat variables for adult sage grouse.

Sagebrush canopy cover is another essential part of sage grouse habitat. Sagebrush canopy cover in all occupied and unoccupied sites measured in the study area meet the guidelines suggested for productive breeding and brood rearing habitat for sage grouse (Connelly et al. 2000). Although sagebrush canopy cover in brome sites is within the guidelines, our data suggest smooth brome may be competitively excluding the establishment of other shrub species and reducing the overall shrub cover to a level that may be insufficient for sage grouse. Sveum et al. (1998) identified total shrub cover in addition to sagebrush canopy cover as an important characteristic of nesting habitat in central Washington.

Sagebrush height and percent decadence were identified as distinguishing variables between adult and occupied habitat sites.
Sage grouse selected taller sagebrush than was randomly available in the study area. However, sagebrush height at occupied habitat sites was within the recommended guidelines (Table 2) (Connelly et al. 2000). This behavior may be a response to the high predation pressure from red fox in the study area (Bunnell and Flinders Unpubl.). The selection of more decadent sagebrush plants, despite no significant difference in plant ages (Table 2), may be an attempt to avoid plant secondary compounds that may be reduced in the less vigorous, more decadent plants as was suggested by Welch et al. (1989) although further research is necessary to analyze this theory.

Our comparisons of adult habitat to available habitat identified sagebrush canopy area and percent grass cover as the only variables discriminating between the two habitat types. Sagebrush in available habitat was younger (16.6 yrs.) and more even-aged (std. 5.9 yrs.) than the sagebrush found at the adult sites (20.5 yrs. std 8.3) (Table 2) resulting in reduced structural diversity which helps explain the difference in sagebrush canopy area. This being the case, we expect the understory composition to change as sagebrush stands mature and increase in structural diversity which may explain the difference in grass cover. However, much of the available habitat was grazed by cattle which likely explains the difference in grass cover.

The discovery that sagebrush age differed significantly between adult and available habitat may be important in understanding the dynamics of sage grouse habitat. Knowing that sagebrush shrubs were significantly older in areas occupied by sage grouse than in the sur-

Table 5. Mean percent cover of forb species measured at sage grouse habitat sites in Strawberry Valley.

\begin{tabular}{|c|c|c|c|c|c|c|}
\hline $\begin{array}{l}\text { Site } \\
\text { Type }\end{array}$ & $\begin{array}{c}\text { Nest } \\
(n=10)\end{array}$ & $\begin{array}{c}\text { Brood } \\
(n=30)\end{array}$ & $\begin{array}{c}\text { Adult } \\
(\mathrm{n}=64)\end{array}$ & $\begin{array}{l}\text { Random } \\
\text { Occupied } \\
(\mathrm{n}=55)\end{array}$ & $\begin{array}{l}\text { Brome } \\
(n=30)\end{array}$ & $\begin{array}{l}\text { Available } \\
(\mathrm{n}=30)\end{array}$ \\
\hline & \multicolumn{6}{|c|}{ - } \\
\hline Pacific aster (Aster chilensis Nees) & 0.01 be & 1.3 acef & $0.8 \mathrm{~b}$ & 1.0 & $0.9 \mathrm{~b}$ & $0.7 \mathrm{~b}$ \\
\hline Wetern yarrow (Achillea millefolium $\mathrm{L}$. ) & 0.2 & $1.1 \mathrm{def}$ & $1.2 \mathrm{e}$ & $0.9 \mathrm{e}$ & $0.2 \mathrm{bcd}$ & 0.4 \\
\hline Prussytoes (Antenaria spp.) & $0.1 \mathrm{~b}$ & 1.4 acdef & $0.4 \mathrm{e}$ & $1.0 \mathrm{ef}$ & $0.1 \mathrm{bcd}$ & $0.2 \mathrm{df}$ \\
\hline Looseflower milkvetch (Astragalus tenellus Pursh.) & 0 & $0.2 \mathrm{e}$ & 0.2 de & $1.0 \mathrm{cef}$ & 0.8 bcdf & $0.3 \mathrm{de}$ \\
\hline Spearleaf fleabane (Erigeron lonchophylus Hook.) & 0 & $0.7 \mathrm{~cd}$ & $0.1 \mathrm{~b}$ & $0.4 \mathrm{~b}$ & 0 & 0 \\
\hline Sulfur eriogonum (Eriogonum umbellatum Torr.) & $3.3 \mathrm{ef}$ & $4.5 \mathrm{ef}$ & $3.5 \mathrm{ef}$ & $3.9 \mathrm{ef}$ & $1.5 \mathrm{abcd}$ & $2.7 \mathrm{abcd}$ \\
\hline Geranium (Geranium spp.) & 0 & 0.6 & 0.4 & 1.2 & 0.4 & 0 \\
\hline Silky lupine (Lupinus sericeus Pursh.) & 4.5 & $2.9 \mathrm{~d}$ & $2.9 \mathrm{~d}$ & $6.0 \mathrm{bc}$ & $3.4 \mathrm{f}$ & $2.5 \mathrm{e}$ \\
\hline Yellow owlclover (Orthocarpus luteus Nutt.) & 0 & 0.9 cef & 0.7 bdef & $1.8 \mathrm{cef}$ & $0.01 \mathrm{bcd}$ & $0.1 \mathrm{~b} \mathrm{~cd}$ \\
\hline Penstemon (Penstemon spp.) & $1.0 \mathrm{cde}$ & $0.6 \mathrm{~cd}$ & 0.3 abe & 0.5 & $0.1 \mathrm{ac}$ & 0.6 \\
\hline Hoods phlox (Phlox hoodii Rich.) & 1.3 bcde & $0.1 \mathrm{a}$ & $0.04 \mathrm{a}$ & $0.2 \mathrm{a}$ & $0.01 \mathrm{a}$ & 0 \\
\hline Douglas knotweed (Polygonum douglasii Greene) & 0 & 0.4 cde & 0.7 bde & 0.7 bcef & $0.7 \mathrm{bcd}$ & $0.7 \mathrm{~d}$ \\
\hline European strawberry (Fragaria vesca L.) & 0 & $0.7 \mathrm{~cd}$ & 0.4 & 0.6 & 0 & 0 \\
\hline Common dandelion (Taraxacum officinale Weber and Wiggers) & $0.1 \mathrm{bcd}$ & 0.9 aef & $1.2 \mathrm{aef}$ & $1.4 \mathrm{ae}$ & $0.1 \mathrm{bcdf}$ & 0.2 \\
\hline Total Forb Cover & 11.04 & 16.01 ef & $13.05 \mathrm{e}$ & 14.75 ef & 8.42 bcd & 9.39 bd \\
\hline
\end{tabular}

Within each column letters indicate site types that are significantly different $(P<0.05)$ from the column site type $(a=$ nest, $b=b r o o d, c=a d u l t, d=$ random occupied, $e=b r o m e, f=$ available) for the row species. 


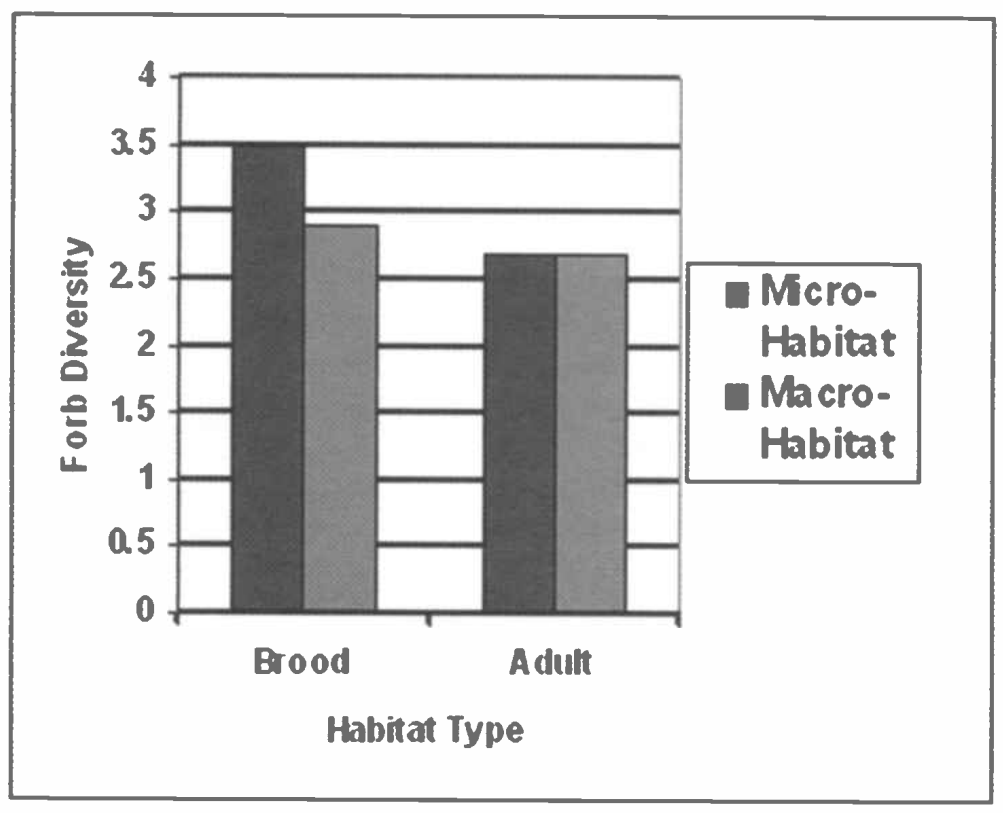

Fig. 4. Forb diversity (\# of species / $1 / 4 \mathrm{~m}^{2}$ ) in micro and macro sage grouse habitat measured at brood and adult habitat sites in Strawberry Valley.

rounding available habitat (Table 2) brings to mind all natural and man-caused disturbance factors that affect occurrence and longevity of big sagebrush. Natural disturbance cycles have been disrupted or eliminated in many sagebrush habitats by altered fire intervals and other factors. Knowledge of the age dynamics of sites that are occupied and unoccupied by sage grouse will help in efforts to restore or mimic natural disturbance regimes to benefit sage grouse.

In our comparison of adult and brome habitat sites, shrub canopy cover, sagebrush canopy area, and percent forb cover were the discriminating variables. Differences in each of these variables may be the result of the competitiveness and abundance of smooth brome an aggressive sod forming grass. It appears that the most limiting, long lasting impact of smooth brome treatments to sage grouse habitat is the reduced cover and diversity of forbs in the understory. Many studies have documented the importance of forbs in sage grouse habitat (Dunn and Braun 1986, Klott and Lindzey 1990, Drut et al. 1994,
Apa 1998). Our data show the competitive ability of smooth brome seriously degrades the value of these areas for sage grouse by greatly reducing forb cover and diversity. Also, the grass component was significantly higher at brome sites than at sage grouse use sites. Important to this issue, is the discovery that the age of sagebrush and sage brush canopy cover in brome habitat did not differ significantly from the age and canopy cover of sagebrush at use sites (Tables 2 and 3), and yet the brome habitat remained unoccupied by sage grouse despite being immediately adjacent to occupied habitat. That past range management practices, intended to decrease sagebrush and increase livestock forage in the Strawberry Valley, continue to have a long lasting negative impact on sage grouse.

Our data suggests that sagebrush and other shrubs growing in areas with tall aggressive grasses, such as smooth brome, are forced to grow tall rather than spreading in order to compete for available sunlight (Table 2). This competition appears to changes the natural growth form of these shrubs and further degrade the areas potential as sage grouse habitat. This interpretation is supported by the fact that the age and height of sagebrush plants growing in brome sites did not differ from the age and height of the sagebrush plants at nest or adult sites, but differed significantly in canopy area (Table 2).

The ability of multivariate statistics (such as logistic regression) to identify fewer discriminating variables than are significant using univariate statistics, stems from simultaneously evaluating the variables for correlation and eliminating all but the most discriminating variables. This reduction in the number of variables identified, as a result of accounting for correlation, allows managers to focus theit efforts on a few identified limiting factors. If these factors are addressed correctly, the correlated factors should also be corrected.

Another advantage of logistic regression over univariate statistical methods is that the resulting function allows managers to calculate the probability that an area of habitat is suitable by measuring only the identified discriminating variables. For example, the function describing differences between adult and brome habitat types in Strawberry Valley is: $\operatorname{logit}(\mathrm{Y})=$ $-2.510+10.650$ (forb cover) +4.754 (shrub canopy cover) +0.559 (sagebrush canepy area), where logit $(\mathrm{Y})=$ the probability of being classified as occupied (or suitable) habitat. Using this function a manager ean calculate the probability that any sagebrush habitat in Strawberry Valley that has an understory of smooth brome will provide suitable adult sage grouse habitat by measuring just the 3 discriminating variables. A manager could also evaluate the effectiveness of a prescribed treatment designed to address limiting factors in brome habitat by measuring the same variables pre and post treatment.

\section{Conclusions}

Occupied sage grouse habitats (adult, brood, nesting, and random) in Strawberry Valley meet the guidelines (Connelly et al.

Table 6. Horizontal Obscurity Cover (\%) at Sage Grouse Nest and Adult Habitat Sites.

\begin{tabular}{|c|c|c|c|c|c|c|c|c|c|}
\hline Site Type & $\begin{array}{l}2.5 \mathrm{~m}(0- \\
33.3 \mathrm{~cm})\end{array}$ & $\begin{array}{c}2,5 \mathrm{~m}(33.3- \\
66.6 \mathrm{~cm})\end{array}$ & $\begin{array}{c}2,5 \mathrm{~m}(66.6- \\
100 \mathrm{~cm})\end{array}$ & $\begin{array}{c}5 \mathrm{~m}(0- \\
33.3 \mathrm{~cm})\end{array}$ & $\begin{array}{c}5 \mathrm{~m}(33.3- \\
66.6 \mathrm{~cm})\end{array}$ & $\begin{array}{c}5 \mathrm{~m}(66.6- \\
100 \mathrm{~cm})\end{array}$ & $\begin{array}{l}10 \mathrm{~m}(0- \\
33.3 \mathrm{~cm})\end{array}$ & $\begin{array}{c}10 \mathrm{~m}(33.3- \\
66.6 \mathrm{~cm})\end{array}$ & $\begin{array}{c}10 \mathrm{~m}(66.6- \\
100 \mathrm{~cm})\end{array}$ \\
\hline & \multicolumn{9}{|c|}{ - } \\
\hline Nest & $99.3 \mathrm{~b}$ & $87.5 \mathrm{ab}$ & $47.2 \mathrm{a}$ & $100 \mathrm{a}$ & $94.8 \mathrm{abc}$ & $74.6 \mathrm{abc}$ & $100 \mathrm{a}$ & $98.3 \mathrm{ab}$ & $87.5 \mathrm{ab}$ \\
\hline Adult & $97.1 \mathrm{a}$ & $86.1 \mathrm{ab}$ & $65.3 \mathrm{ab}$ & $99.6 \mathrm{a}$ & $95.9 \mathrm{a}$ & $84.3 \mathrm{a}$ & $100 \mathrm{a}$ & $98.9 \mathrm{ab}$ & $93.2 \mathrm{a}$ \\
\hline Brood & $96.2 \mathrm{a}$ & $78.1 \mathrm{a}$ & $52.2 \mathrm{a}$ & $99.0 \mathrm{a}$ & $90.6 \mathrm{~b}$ & $71.0 \mathrm{~b}$ & 99.9 a & 95.5 a & $84.5 \mathrm{~b}$ \\
\hline Random occupied & $95.7 \mathrm{a}$ & $79.9 \mathrm{a}$ & $58.0 \mathrm{a}$ & $98.1 \mathrm{a}$ & $91.4 \mathrm{ab}$ & $74.3 \mathrm{ab}$ & $99.8 \mathrm{a}$ & $96.6 \mathrm{ab}$ & $91.6 \mathrm{a}$ \\
\hline Brome Habitat & $99.6 \mathrm{~b}$ & $89.1 \mathrm{~b}$ & $72.4 \mathrm{~b}$ & $99.9 \mathrm{a}$ & $97.2 \mathrm{c}$ & $88.1 \mathrm{c}$ & $100 \mathrm{a}$ & $99.2 \mathrm{~b}$ & $96.2 \mathrm{a}$ \\
\hline Available Habitat & $98.6 \mathrm{a}$ & $85.7 \mathrm{ab}$ & $62.4 \mathrm{ab}$ & $100 \mathrm{a}$ & $95.6 \mathrm{abc}$ & $76.1 \mathrm{abc}$ & $100 \mathrm{a}$ & $99.0 \mathrm{ab}$ & $91.5 \mathrm{ab}$ \\
\hline
\end{tabular}

Within each column, means with different letters are significantly different (alpha $=0.05$ ). 
2000 ) in all respects. However, our data suggest the recommended guidelines may be conservative in relation to some habitat components. For example, sage grouse in the strawberry valley selected taller sagebrush than was randomly available despite the fact the randomly available sagebrush was within the recommended guidelines (Table 2). In addition, sage grouse broods selected micro habitats with significantly greater forb cover then the surrounding habitat even though forb cover within the surrounding habitat was within the recommended guidelines for brood habitat (Fig. 3).

Our data confirmed the importance of the vegetative components outlined by Connelly et al. (2000) to sage grouse habitat selection. In addition, we identified other important aspects of sage grouse habitat including: 1) canopy area of sagebrush plants, 2) percent decadence of sagebrush plants, and 3) age of sagebrush stands as potentially important components of adult habitat selection (Table 2). Forb diversity was also identified as a potentially important component of brood habitat selection (Fig. 4).

Lastly, our comparisons of occupied and unoccupied sagebrush grass habitat in the Strawberry Valley, quantified the negative impacts of past range management practices that replaced the native forbs and bunch grasses with an understory of smooth brome. Our data also suggests that available habitat may be limited by the age of available sagebrush stands and a lack of grass and forb cover and forb diversity in the understory (Tables 4 and 5).

Sage grouse are an important component of sagebrush communities. Sage grouse cannot survive without sagebrush. The more we understand about this dynamic biotic relationship the better are our chances to preserve and enhance sage grouse populations. Further work is needed on the age dynamics of big sagebrush stands in known sage grouse habitats. We also need to know the age dynamics of occupied and unoccupied sage grouse habitats in association with other species and subspecies of sagebrush (e.g. basin big sagebrush (Artemisia tridentata tridentata Nutt.), Wyoming big sagebrush (Artemisia tridentata wyomingensis Beetle and Young), 3 tip sagebrush (Artemisia tripartita Rybd.) and black sagebrush (Artemisia nova A. Nels.). Data are needed to evaluate age differences in sagebrush stands used for different purposes (ie. nesting, brood rearing, etc.) in all sagebrush types. More information is needed regarding adult sage grouse habitat, and we need to continue to expand our knowledge of nesting and brood habitats.

\section{Literature Cited}

Apa, A.D. 1998. Habitat use and movements of sympatric sage and Columbian sharp-tailed grouse in southeastern Idaho. PhD. Diss., University of Idaho, Moscow, Ida.

Autenreith, R.E. 1981. Sage grouse management in Idaho. Wildlife Bulletin 9. Idaho Dept. of Fish and Game. Boise, Ida.

Bonham, C. D. 1989. Measurements for terrestrial vegetation. John Wiley and Sons Inc. New York, N.Y. 338pp

Braun, C.E., T. Britt, and R.O. Wallstead. 1977. Guidelines for maintenance of sage grouse habitats. Wildl. Soc. Bul. 5:99-106.

Connelly, J.W., M.A. Shroeder, A.R. Sands, and C.E. Bruan. 2000. Guidelines to manage sage grouse populations and their habitats. Wildl. Soc. Bul. 28(4):967-985.

Connelly, J.W., W.L. Wakkinen, A.D. Apa, and K.P. Reese. 1991. Sage grouse use of nest sites in southeastern Idaho. J. Wildl. Manage. 55:521-524.

Drut, M.S., J.A. Crawford, and M.A. Gregg. 1994. Brood habitat use by sage grouse in Oregon. Great Basin Nat. 54:170-176.

Dunn, P.O. and C.E. Braun. 1986. Summer habitat use by adult female and juvenile sage grouse. J. Wildl. Manage. 50:228-235.

Fischer, R.A. K.P. Reese, and J.W. Connelly. 1996. An investigation on fire effects within xeric sage grouse brood habitat. J. Range Manage. 49:194-198.

Fischer, R.A., A.D. Apa, W.L. Wakkinen, K.P. Reese, and J.W. Connelly. 1993. Nesting-area fidelity of sage grouse in southeastern Idaho. Condor 95: 1038-1041.

Ferguson, C.W. 1964. Annual rings in big sagebrush. Papers of the Lab. of Tree-Ring Research. Univ. Arizona Press. Tucson, Ariz. 95pp.

Gray, G.M. 1967. An ecological study of sage grouse broods with reference to nesting, movements, food habits and sagebrush strip spraying in the Medicine Lodge drainage, Clark County, Idaho. M.S. Thesis, University of Idaho, Moscow, Ida.

Giesen, K.M., T.J. Schoenberg, and C.E. Braun. 1982. Methods for trapping sage grouse in Colorado. Wildl. Soc. Bull. 10:224-231

Gregg, M.A. 1991. Use and selection of nesting habitat by sage grouse in Oregon. Unpublished master's thesis, Oregon State University, Corvallis. Ore. 46pp.

Gregg, M.A., J.A. Crawford, M.S. Drut, and A.K. Delong. 1994. Vegetational cover and predation of sage grouse nests in Oregon. J. Wildl. Manage. 58:162-166.

Griner, L. A. 1939. A study of sage grouse (Centrocercus urophasianus), with special reference to life history, habitat requirements, and numbers and distribution. M.S. Thesis, Utah State Agricultural College, Logan, Ut. $111 \mathrm{pp}$.

Hosmer, D.W. and S. Lemeshow. 2000. Applied logistic regression. Wiley and Sons, New York, N.Y. 373pp.

Hulet, B.V. 1983. Selected response of sage grouse to prescribed fire, predation, and grazing by domestic sheep in southeastern Idaho. M.S. Thesis, Brigham Young University, Provo, Utah.
Klebenow, D.A. 1969. Sage grouse nesting and brood habitat in Idaho. J. Wildl. Manage. 33:649-662.

Klott, J.H. and F.G. Lindzey. 1990. Brood habitats of sympatric sage grouse and columbian sharp-tailed grouse in Wyoming. J. Wildl. Manage. 54:84-88.

Ludwig, J.A. and J.F. Reynolds. 1988. Statistical ecology a primer on methods and computing. John Wiley and Sons Inc. New York, N.Y. 337 pp

Marcstrom V., R. E. Kenward, and $M$. Karlbom. 1989. Survival of ring-necked pheasants with backpacks, necklaces, and leg bands. J. Wildl. Manage. 53(3):808-810

Martin, N.S. 1970. Sagebrush control related to habitat and sage grouse occurrence. J. Widl. Manage. 34:313-320.

Martin, R.C. 1990. Sage grouse responses to wildfire in spring and summer habitats. M.S. Thesis, University of Idaho, Moscow, Ida.

Musil, D., K.P. Reese, and J.W. Connelly. 1994. Nesting and summer habitat use by translocated sage grouse (Centrocercus urophasianus) in central Idaho. Great Basin Nat. 54:228-233.

Nelle, P.G. 1998. The long term effects of fire on sage grouse nesting and brood rearing habitats on the Upper Snake River Plain. M.S. Thesis, University of Idaho, Moscow, Ida.

Peterson, B.E. 1980. Breeding and nesting ecology of female sage grouse in North Park, Colorado. M.S. Thesis. Colorado State University, Fort Collins, Colo.

Sveum, C.M., W.D. Edge, and J.A. Crawford. 1998. Nesting habitat selecton by sage grouse in south-central Washington. J. Range Manage. 51:265-269.

Schoenberg, T.J. 1982. Sage grouse movements and habitat selection in North Park, Colorado. M.S. Thesis, Colorado State University, Fort Collins, Colo.

Wakkinen, W.L. 1990. Net site characteristics and spring-summer movements of migratory sage grouse in southeastern Idaho. M.S. Thesis, University of Idaho, Moscow, Ida.

Wakkinen, W.L., K.P. Reese, and J.W. Connelly. 1992. Sage grouse nest locations in relation to leks. J. Widl. Manage. 56:381-383.

Wallestad, R.O. 1971. Summer movement and habitat use by sage grouse broods in Montana. J. Wildl. Manage. 35:129-136.

Wallestad, R.O. and P. Schadweiller. 1974. Breeding season movements and habitat selection of male sage grouse. J. Widl. Manage. 38:634-637.

Webb, D.R. 1993. Sage Grouse nest site characteristics and microclimates in wyoming: final report to the Wyoming Department of Fish and Game. Laramie Wyo.: Department of Biology, University of Wyoming. Laramie Wyo. 20pp.

Welch, B. L., J.C. Pederson, and R.L. Rodriguez. 1989. Monoterpenoid content of sage grouse ingesta. J. Chem. Ecol. 15(3): 961-969. 